\title{
The Effect of Multimedia Presentation on the Explanation Text Writing Skills of Eighth Grade at Al- Bukhary Rantauprapat Islamic Junior High School 2020-2021 Academic Year
}

\author{
Rahimi $^{1}$, Sutikno, ${ }^{2, *}$, Ilhamdi Zefry Syuhada ${ }^{1}$, Pandu Wilantara $^{1}$, and Nina Febrina ${ }^{1}$ \\ ${ }^{1}$ Postgraduate of Universitas Muslim Nusantara Al Washliyah Medan, Indonesia \\ ${ }^{2}$ Lecturer of Universitas Muslim Nusantara Al Washliyah Medan, Indonesia \\ *Corresponding author email: sutikno@umnaw.ac.id
}

\begin{abstract}
This research is aimed at determining how the influence of multimedia presentation (PowerPoint) on explanatory text writing skills in eighth grade students at Al-Bukhary Rantauprapat Islamic Junior High School 2020 academic year. The research model used in this research is the researcher used the quantitative method, which is a study that uses data in the form of numbers as a means of finding information about what we want to know. Then the researcher chose the one-group pretest-posttest design research type. The sample in this research at Al-Bukhary Rantauprapat Islamic Junior High School, totaling 40 students, used multimedia presentations in the form of PowerPoint on a laptop. The hypothesis used in this study is the use of multimedia presentations in writing explanatory text has a significant effect. These results are shown from the pretest average value of 59.67. After being given treatment in the form of multimedia presentations (Powerpoint), the average post-test score has increased by 86.9. Based on the results of the test between the pretest and posttest, it can be seen that the t-count (3.313) and t-table (2.024) shows that t-count $>\mathrm{t}$-table. These results were obtained due to the choice of the right media and the ability of the teacher to convey the material. This needs to be supported by complete facilities to provide a variety of media that support learning.
\end{abstract}

Keywords: Multimedia Presentation, Writing Skills, Explanatory Text

\section{INTRODUCTION}

Education is an effort made deliberately and systematically to motivate, nurture, assist, and guide someone to develop all their potential so that they achieve a better quality of self. In improving the quality of the world of education has its own process, the educational process is an effort to change for the better so that good cooperation can be achieved between the components contained in it. A learning activity in the form of an interaction between teachers and students and having specific goals is a component in the learning process [1]-[3].

In an effort to improve the quality of education, the quality of teachers is one component that has a very important role. One of the efforts to improve the quality of education in schools is by improving the teaching and learning process or learning. A teacher must be creative in order to change the teaching and learning process strategy to be more interesting and less monotonous for students. Strategies or learning tools in the learning process are expected to become translators for students regardless of the material presented by the teacher [4]-[6]. In particular, the material in Indonesian language learning is measured by the student's ability to master four language skills, namely listening, speak, read, and write [7]-[8].

The four aspects of language skills are communication tools that cannot stand alone with one another and are interrelated and mutually determining. Based on the level 
of difficulty, the language skill that is considered difficult is writing. In this case, writing involves three stages, namely: 1) prewriting stage, 2) writing stage, and 3) post writing stage.

Teaching Indonesian and Literature plays an important role in schools. One of them is teaching writing. Writing is a language skill found at all levels of education, from preschool to college level. These skills are very important for the development of a person, especially students and university students. The skill of writing explanatory texts is one of the closest examples for students to express their experiences. Explanatory text is a type of text that describes the stages or processes of a phenomenon, be it a natural, social phenomenon or an event experienced by the students themselves. Therefore, students can easily express their writing ideas according to the phenomena they observe, and about how and why the process of this phenomenon occurs [9]-[12].

For this reason, teachers are required to be creative in the learning and teaching process. The teacher can use a method or an innovative learning media. One of them is power point media or multimedia presentations. Multimedia presentation is a form of innovative learning media. Because every lesson need effort to develop the ability of teachers in various fields, especially technology [13].

Based on the description above, the researcher is interested in conducting research by taking the title "The Effect of Multimedia Presentation on The Explanation Text Writing Skills of Eighth Grade at Al-Bukhary Rantauprapat Islamic Junior High School 2020-2021 Academic Year".

\section{LITERATURE REVIEW}

Language skills have four skills, namely listening, speaking, reading, and writing. As a language skill, writing is a complex activity because writers are required to be able to compile and organize written content and pour it into written forms. According to Dalman [14], writing is a process of conveying thoughts, dreams, feelings in the form of meaningful symbols/signs/writing. In writing activities, there is an activity of arranging, compiling, describing a symbol, sign, writing in the form of a collection of letters that form words, conclusions of words that form sentences, collections of sentences forming paragraphs, and a collection of paragraphs that form a complete and meaningful discourse.

Writing skills can be used to record, record, persuade, inform and influence readers. This can be achieved well if the writer, namely students, is able to compile and arrange writing and thoughts and express his writing clearly, fluently and communicatively [15]. Careful attention and tenacity and mastery of a lot of vocabulary, as well as a sense of resignation to make a writing as well as a fairly broad knowledge is needed in writing skills.

Explanatory Text is a type of text that describes the logical relationship of several events. In the explanatory text, an event arises because there are other events before and these events result in other events afterwards.
Explanatory text aims to explain why and how the natural process occurs or the process of natural and social phenomena works [15].

Priyatni argues, an explanatory text is a text that comes from the author's questions regarding, why, and how a phenomenon occurs, which contains an explanation of processes related to natural, social, scientific, cultural and other phenomena.

From the above opinion, it can be concluded that explanatory text writing skills is a process of pouring out ideas or text ideas that explain the process of a series of natural events and social events that can be used as information givers to others.

\section{METHODOLOGY}

The word media comes from the Latin medius which literally means 'middle', 'intermediary', or introduction. In Arabic, the media is an intermediary or messenger from the sender to the recipient of the message [16]. Meanwhile, according to Fleming in Arsyad [16], the media shows its function or role, namely managing an effective relationship between the two main parties in the learning process of students and lesson content.

Multimedia presentation is part of media. Information and technology-based have also provided lots contributions to improve learning results. Multimedia presentation is a learning media that utilizes an application called PowerPoint. This application is incorporated in the Microsoft Office which is already available in it which no longer needs to be downloaded and is more often found and is also familiar in the world of education which is relatively easy and cheap compared to other applications. Through explanatory text the reader is presented in order to understand the process of the occurrence of various kinds of natural and social phenomena. Information obtained through explanatory text will enrich and add insight to the reader. This is because this explanatory text provides information or news in depth and in detail.

In the learning process of writing explanatory text, this material is one of the lessons that uses critical thinking and broad knowledge from students. Therefore, the learning process using multimedia presentations can be useful. Students' thinking abilities can develop with the help of this media.

In learning, students are taught to relate what is learned with how this knowledge is used or applied in new situations. Students will be taught how to be critical of a problem or phenomenon it faces.

The steps of the learning process in writing explanatory text using multimedia presentations are as follows.

a. The teacher explains the importance of using explanatory text in everyday life and proposes a natural phenomenon or event, technology through slides or PowerPoints.

b. The teacher asks students to look at and criticize an existing problem that is presented in PowerPoint and Student books. 
c. The teacher groups students and answers any questions given as the focus of learning.

d. Students collect data and discuss to obtain information related to the explanation of a phenomenon they encounter.

e. Students make works about the process of occurring events, according to the rules of learning to write explanatory text.

f. Students together with the teacher conclude learning about writing explanatory text.

This type of research is a research using the quantitative method, which is a study that uses data in the form of numbers as a means of finding information about what we want to know. Researchers do a pretest and posttest. In that class, pretest and posttest were carried out, at the time of the pretest, the group had not been given treatment in the form of multimedia presentation media, while during the posttest the group had been given treatment. So, initially the researcher did the pretest by providing material about explanatory text. Next, the researcher conducts a posttest with the same criteria by learning using a multimedia presentation (Powerpoint) in the form of a description of natural disasters, an animated display of environmental pollution, forest burning and so on. After that the researcher gives the student a task by writing explanatory text.

After that it can be seen the differences in student writing before and after being given treatment in the form of multimedia presentations. In addition, it can be seen the effect of using multimedia presentations on students' writing skills.

\section{RESULTS AND DISCUSSION}

This research was conducted to prove whether there was an effect of the learning media (multimedia presentations) given to students on explanatory text writing skills, before using the media in the initial conditions of students who were not given treatment in the form of multimedia presentations still in the same condition. Before being given the treatment, the researcher only used the lecture method and learning resources that were usually used by Indonesian language teachers at the school. Pretest (before the treatment is given) is used in the skills of writing explanatory text with free themes, according to their respective experiences. After completing the pretest assessment, the next researcher conducts a posttest giving treatment in the form of using a multimedia presentation in the form of a PowerPoint.

When using the media, the researcher gave an assignment with the theme "Rain". The treatment was given at different hours and days. Because the time is not enough and to avoid boredom during the learning process because the researchers use the same material. After the assignments are collected, then it is known the value of the students who have been given treatment.

Based on the results of the posttest, the students' scores have increased. From the results of research and data processing, it can be seen that the post-test results are better than the pretest results, this is shown from the pretest average value of 59.67 after being given treatment in the form of multimedia presentations (Powerpoint), the average post-test score has increased by 86.90 .

Based on the results of this study it can be said that the effect of Multimedia Presentation on writing explanatory text skills in students can be categorized as good, this is because students already understand how to write explanatory text correctly according to its structure, it's just that there are deficiencies when working on it, as well as the use of language that is more scientific and interesting, but with multimedia presentations students become more motivated and more enthusiastic during the learning process.

\subsection{Pretest Data (Before Using Multimedia Presentations)}

Based on the Table, it can be seen in aspect I (use of conjunctions) that the lowest score of students from 1 to 25 is 5 while the highest score of students is 19 . While in aspect II (verb) the lowest score of students from 1 to 25 is 5 while the student's highest score is 19 . In aspect III (general words) the lowest score of students from 1 to 25 is 5 while the highest score is 22 . In the IV aspect (explanatory sentence) the lowest score of students from 1 to 25 is 5 while the highest score is 19 .

Table 1. List of Student Names for Pretest Explanatory Text Test

\begin{tabular}{|c|l|c|c|c|c|c|}
\hline \multirow{2}{*}{ No } & \multicolumn{1}{|c|}{ Name } & \multicolumn{3}{|c|}{ Assessment Aspects } & \multirow{2}{*}{ Total } \\
\cline { 3 - 6 } & & I & II & III & IV & \\
\hline & $\begin{array}{l}\text { Aditia } \\
\text { Muhammad } \\
\text { Akbar }\end{array}$ & 19 & 19 & 19 & 19 & 76 \\
\hline 2 & $\begin{array}{l}\text { Agung } \\
\text { Nurcahyono }\end{array}$ & 19 & 15 & 19 & 15 & 68 \\
\hline 3 & Ahmad Doli & 19 & 17 & 19 & 17 & 72 \\
\hline 4 & $\begin{array}{l}\text { Albabayyinal } \\
\text { Darwis }\end{array}$ & 15 & 11 & 19 & 11 & 56 \\
\hline 5 & $\begin{array}{l}\text { Andre } \\
\text { Pratama } \\
\text { Putra }\end{array}$ & 17 & 15 & 15 & 15 & 62 \\
\hline 6 & $\begin{array}{l}\text { Ardiana } \\
\text { Fitria } \\
\text { Ritonga }\end{array}$ & 11 & 5 & 5 & 17 & 38 \\
\hline 7 & $\begin{array}{l}\text { Ardiyansyah } \\
\text { Situmorang }\end{array}$ & 19 & 19 & 15 & 19 & 72 \\
\hline 8 & $\begin{array}{l}\text { Arfan } \\
\text { Sipahutar }\end{array}$ & 19 & 5 & 19 & 19 & 62 \\
\hline 9 & Aulia Ulpa & 19 & 19 & 19 & 19 & 76 \\
\hline 10 & $\begin{array}{l}\text { Bunga } \\
\text { Kartika }\end{array}$ & 19 & 19 & 19 & 19 & 76 \\
\hline 11 & $\begin{array}{l}\text { Elpiani } \\
\text { Brbatubara }\end{array}$ & 19 & 15 & 15 & 15 & 64 \\
\hline 12 & $\begin{array}{l}\text { Fadillah } \\
\text { Azannah Ray }\end{array}$ & 19 & 19 & 19 & 19 & 76 \\
\hline & & & & & \\
\hline
\end{tabular}




\begin{tabular}{|c|c|c|c|c|c|c|}
\hline 13 & $\begin{array}{l}\text { Febriansyah } \\
\text { Munthe }\end{array}$ & 15 & 19 & 19 & 19 & 72 \\
\hline 14 & $\begin{array}{l}\text { Fuad Taufiq } \\
\text { Wicaksono }\end{array}$ & 19 & 19 & 19 & 19 & 76 \\
\hline 15 & Gusti & 19 & 18 & 18 & 18 & 73 \\
\hline 16 & $\begin{array}{l}\text { Hardiyansyah } \\
\text { Putra }\end{array}$ & 19 & 9 & 9 & 9 & 46 \\
\hline 17 & Juliansyah & 18 & 19 & 19 & 19 & 75 \\
\hline 18 & $\begin{array}{l}\text { M. Roni } \\
\text { Maulana }\end{array}$ & 9 & 5 & 19 & 5 & 38 \\
\hline 19 & $\begin{array}{l}\text { M. Haris } \\
\text { Hasibuan }\end{array}$ & 19 & 12 & 12 & 15 & 58 \\
\hline 20 & $\begin{array}{l}\text { Mutiara } \\
\text { Wulandari } \\
\text { Nst }\end{array}$ & 5 & 11 & 11 & 19 & 46 \\
\hline 21 & $\begin{array}{l}\text { Najwa } \\
\text { Hamdani }\end{array}$ & 15 & 19 & 19 & 9 & 62 \\
\hline 22 & Neng Risya & 19 & 13 & 13 & 10 & 55 \\
\hline 23 & Nur Devi & 9 & 12 & 18 & 12 & 51 \\
\hline 24 & $\begin{array}{l}\text { Pepry } \\
\text { Ardiyansyah }\end{array}$ & 10 & 12 & 15 & 9 & 46 \\
\hline 25 & $\begin{array}{l}\text { Rafly } \\
\text { Prasetya } \\
\text { Harahap }\end{array}$ & 12 & 15 & 19 & 15 & 61 \\
\hline 26 & $\begin{array}{l}\text { Raysyah } \\
\text { Nabilah }\end{array}$ & 15 & 19 & 5 & 10 & 49 \\
\hline 27 & $\begin{array}{l}\text { Ridho } \\
\text { Juliandi }\end{array}$ & 15 & 9 & 19 & 19 & 62 \\
\hline 28 & Rifki Aditya & 10 & 10 & 40 & 40 & 40 \\
\hline 29 & Ripaldi & 19 & 12 & 19 & 13 & 63 \\
\hline 30 & $\begin{array}{l}\text { Rizka Astri } \\
\text { Julianda }\end{array}$ & 10 & 15 & 19 & 11 & 55 \\
\hline 31 & $\begin{array}{l}\text { Roy Reza } \\
\text { Nasution }\end{array}$ & 13 & 15 & 15 & 15 & 58 \\
\hline 32 & $\begin{array}{l}\text { Ryan Kirana } \\
\text { Panggabean }\end{array}$ & 11 & 10 & 10 & 17 & 48 \\
\hline 33 & $\begin{array}{l}\text { Sarifa } \\
\text { Anggraini }\end{array}$ & 15 & 19 & 19 & 17 & 70 \\
\hline 34 & Septia & 17 & 10 & 10 & 18 & 55 \\
\hline 35 & $\begin{array}{l}\text { Sisdi } \\
\text { Amanda }\end{array}$ & 17 & 11 & 11 & 16 & 55 \\
\hline 36 & $\begin{array}{l}\text { Syaharuddin } \\
\text { Ritonga }\end{array}$ & 18 & 15 & 15 & 15 & 63 \\
\hline 37 & $\begin{array}{l}\text { Tanwirul } \\
\text { Azhan }\end{array}$ & 16 & 14 & 14 & 12 & 56 \\
\hline 38 & $\begin{array}{l}\text { Tio Rama } \\
\text { Dana }\end{array}$ & 15 & 10 & 10 & 15 & 50 \\
\hline 39 & $\begin{array}{l}\text { Wulan Rama } \\
\text { Dini }\end{array}$ & 12 & 11 & 11 & 12 & 46 \\
\hline 40 & Wulandari & 15 & 15 & 15 & 15 & 60 \\
\hline
\end{tabular}

\subsection{Posttest Data (After Using Multimedia Presentations)}

Based on the Table 2, it can be seen in aspect I (use of conjunctions) that the lowest score of students from 1-25 is 15 while the highest score of students is 25 . While in aspect II (verb) the lowest score of students from 1-25 is
15 while the student's highest score was 25 . In aspect III (general words) the lowest score of students from 1-25 was 15 while the highest score was 25 . In the fourth aspect (explanatory sentence) the lowest score of students from 1 to 25 was 15 while the highest score was 25

Table 2. List of Student's Name in the Postest Explanatory Text Test

\begin{tabular}{|c|c|c|c|c|c|c|}
\hline \multirow{2}{*}{ No } & \multirow{2}{*}{ Name } & \multicolumn{4}{|c|}{ Assessment Aspects } & \multirow{2}{*}{ Total } \\
\hline & & I & II & III & IV & \\
\hline 1 & $\begin{array}{l}\text { Aditia Muhammad } \\
\text { Akbar }\end{array}$ & 22 & 20 & 25 & 25 & 90 \\
\hline 2 & $\begin{array}{l}\text { Agung } \\
\text { Nurcahyono }\end{array}$ & 25 & 18 & 25 & 20 & 90 \\
\hline 3 & Ahmad Doli & 23 & 18 & 20 & 18 & 77 \\
\hline 4 & $\begin{array}{l}\text { Albabayyinal } \\
\text { Darwis }\end{array}$ & 25 & 25 & 23 & 22 & 95 \\
\hline 5 & $\begin{array}{l}\text { Andre } \\
\text { Putra }\end{array}$ & 20 & 18 & 20 & 20 & 78 \\
\hline 6 & $\begin{array}{ll}\text { Ardiana } & \text { Fitria } \\
\text { Ritonga } & \end{array}$ & 20 & 20 & 20 & 16 & 76 \\
\hline 7 & $\begin{array}{l}\text { Ardiyansyah } \\
\text { Situmorang }\end{array}$ & 20 & 25 & 20 & 25 & 90 \\
\hline 8 & Arfan Sipahutar & 22 & 20 & 16 & 19 & 77 \\
\hline 9 & Aulia Ulpa & 16 & 21 & 20 & 21 & 78 \\
\hline 10 & Bunga Kartika & 25 & 20 & 20 & 25 & 90 \\
\hline 11 & Elpiani Brbatubara & 18 & 22 & 15 & 22 & 77 \\
\hline 12 & $\begin{array}{l}\text { Fadillah Azannah } \\
\text { Ray }\end{array}$ & 19 & 22 & 15 & 22 & 77 \\
\hline 13 & $\begin{array}{l}\text { Febriansyah } \\
\text { Munthe }\end{array}$ & 25 & 20 & 25 & 25 & 95 \\
\hline 14 & $\begin{array}{l}\text { Fuad Taufiq } \\
\text { Wicaksono }\end{array}$ & 24 & 18 & 20 & 20 & 82 \\
\hline 15 & Gusti & 25 & 25 & 25 & 20 & 95 \\
\hline 16 & $\begin{array}{l}\text { Hardiyansyah } \\
\text { Putra }\end{array}$ & 21 & 15 & 17 & 23 & 76 \\
\hline 17 & Juliansyah & 22 & 22 & 18 & 20 & 82 \\
\hline 18 & M. Roni Maulana & 21 & 20 & 20 & 23 & 84 \\
\hline 19 & M. Haris Hasibuan & 23 & 25 & 25 & 25 & 98 \\
\hline 20 & $\begin{array}{l}\text { Mutiara } \\
\text { Wulandari Nst }\end{array}$ & 25 & 25 & 20 & 25 & 95 \\
\hline 21 & Najwa Hamdani & 20 & 20 & 25 & 25 & 90 \\
\hline 22 & Neng Risya & 23 & 25 & 25 & 25 & 98 \\
\hline 23 & Nur Devi & 20 & 25 & 25 & 21 & 91 \\
\hline 24 & $\begin{array}{l}\text { Pepry } \\
\text { Ardiyansyah }\end{array}$ & 22 & 20 & 20 & 20 & 82 \\
\hline 25 & $\begin{array}{ll}\text { Rafly } & \text { Prasetya } \\
\text { Harahap } & \\
\end{array}$ & 18 & 17 & 25 & 19 & 79 \\
\hline 26 & Raysyah Nabilah & 23 & 23 & 15 & 24 & 85 \\
\hline 27 & Ridho Juliandi & 25 & 25 & 25 & 23 & 98 \\
\hline 28 & Rifki Aditya & 25 & 25 & 25 & 20 & 95 \\
\hline 29 & Ripaldi & 22 & 20 & 25 & 25 & 92 \\
\hline 30 & $\begin{array}{ll}\text { Rizka } & \text { Astri } \\
\text { Julianda } & \\
\end{array}$ & 21 & 20 & 20 & 23 & 84 \\
\hline 31 & $\begin{array}{ll}\text { Roy } & \text { Reza } \\
\text { Nasution } & \\
\end{array}$ & 16 & 20 & 25 & 18 & 79 \\
\hline 32 & Ryan & 19 & 25 & 20 & 25 & 89 \\
\hline
\end{tabular}




\begin{tabular}{|l|l|l|l|l|l|l|}
\hline & Panggabean & & & & & \\
\hline 33 & Sarifa Anggraini & 20 & 23 & 25 & 25 & 93 \\
\hline 34 & Septia & 25 & 25 & 21 & 25 & 93 \\
\hline 35 & Sisdi Amanda & 20 & 25 & 22 & 15 & 82 \\
\hline 36 & $\begin{array}{l}\text { Syaharuddin } \\
\text { Ritonga }\end{array}$ & 20 & 20 & 25 & 23 & 88 \\
\hline 37 & Tanwirul Azhan & 25 & 22 & 23 & 25 & 95 \\
\hline 38 & Tio Rama Dana & 15 & 22 & 20 & 25 & 82 \\
\hline 39 & Wulan Rama Dini & 23 & 23 & 16 & 25 & 87 \\
\hline 40 & Wulandari & 25 & 22 & 22 & 20 & 89 \\
\hline
\end{tabular}

\section{CONCLUSION}

Based on the results after conducting research and data processing on students in eighth grade at Al-Bukhary Rantauprapat Islamic Junior High School, it can be seen that the effect of multimedia presentations (PowerPoint) on the writing skills of explanatory text carried out by researchers is in the good category. These results are shown from the pretest average value of 59.67. After being given treatment in the form of multimedia presentations (Powerpoint), the average posttest score increased by 86.9. Based on the results of the t-test between pretest and posttest, it can be seen in t-count (3.313) and t-table (2.024). So, Ha was accepted and Ho was rejected, that means there is a significant influence in the use of multimedia presentations on the writing skills of students in explanatory texts at Al-Bukhary Rantauprapat Islamic Junior High School. The sound of $\mathrm{Ha}$, that means there is an effect of multimedia presentations on the writing skills thus it can be concluded that multimedia presentation (Powerpoint) has an influence on the explanatory text writing skills of students at Al-Bukhary Rantauprapat Islamic Junior High School.

\section{REFERENCES}

[1] I. C. Chahine, F. Khan, Improving the Quality of Learning Outcomes and Enhancing the Performance of Education Systems: A Case Study in Kuwait. International Journal of Learning, Teaching and Educational Research, 10 (1) (2015), 1-21.

[2] Fajriah, Learning Journal: Improving Teaching Strategies Through Students' Reflections. Sukma: Jurnal Pendidikan, 1 (2) (2017), 301-327.

[3] D. Sulisworo, The Contribution of the Education System Quality to Improve the Nation's Competitiveness of Indonesia. Journal of Education and Learning, 10 (2) (2016), 127-138.

[4] A. Paolini, Enhancing Teaching Effectiveness and Student Learning Outcomes. The Journal of Effective Teaching, 15 (1) (2015), 20-33.
[5] F. Gull, S. Shehzad, Effects of Cooperative Learning on Students' Academic Achievement. Journal of Education and Learning, 9 (3) (2015), 246-255.

[6] S. Widoretno, S. Dwiasturi, Improving Students' Thinking Skill Based on Class Interaction in Discovery Instructional: A Case of Lesson Study. Jurnal Pendidikan IPA Indonesia, 8 (3) (2019), 347-353.

[7] H. Aydogan, A. A. Akbarov, The Four Basic Language Skills, Whole Language \& Intergrated Skill Approach in Mainstream University Classrooms in Turkey. Mediterranean Journal of Social Sciences, 5 (9) (2014), 672-680.

[8] L. M. Sadiku, The Importance of Four Skills Reading, Speaking, Writing, Listening in a Lesson Hour. European Journal of Language and Literature Studies, 1 (1) (2015), 29-31.

[9] R. Autila, M. Theresia, Improving Students' Writing Skill of Recount Text Through Writing and Peer Editing Technique. Proceedings of the Sixth International Conference on English Language and Teaching (ICOELT-6), (2018), 149-157.

[10] R. Fahmi, Students' Writing Competence in Writing Daily Journal (An Experimental Research at the Second Year Students of Senior High School of Darul Ulum Banda Aceh). Thesis, Faculty of Tarbiyah and Teacher Training Ar-Raniry State Islamic University Darussalam, Banda Aceh, (2016).

[11] M. M. Maharani, Improving Students' Writing Through Diary Writing. The 1st Education and Language International Conference Proceedings, Center for International Language Development of Unissula, (2017), 473-478.

[12] E. Iftanti, Improving Student's Writing Skills Through Writing Journal Articles. Lingua Scientia, 8 (1) (2016), 1-22.

[13] M. Zaim, The Power of Multimedia to Enhance Learners' Language Skills in Multilingual Class. Proceedings of the Fourth International Seminar onEnglish Language and Teaching (ISELT-4), (2016), 22-29.

[14] Dalman, Keterampilan Menulis. Jakarta: Raja Grafindo Prasada, (2014).

[15] N. Salfera, Meningkatkan Kemampuan Menulis Teks Eksplanasi dengan Menggunakan Media Gambar Berseri Pada Siswa Kelas VII. Jurnal EDUCATIO, 3 (2) (2017), 32-43.

[16] I. Arsyad, Media Pembelajaran. Jakarta: Raja Grafindo Prasada, (2013). 